\title{
Huippuyksiköiden palkitsemiskriteerit alttiita suhdanteille?
}

Kimmo Ketonen \& Kari Nyyssölä 1996. Palkitsemisen politiikka. Koulutussosiologian tutkimuskeskus, raportti 39. Turun yliopisto, Pallosalama OY, 157 sivua.

K etonen ja Nyyssölä ovat kirjoittaneet ajankohtaisen raportin, jota on käsitelty myös päivälehtien sivuilla. He taustoittavat yliopistojen huippuyksikkö-, tuloksellisuus- ja arviointikeskustelua tarkastelemalla mainittujen teemojen kehittymistä suomalaisessa korkeakoulu- ja tiedepolitiikassa 1970 luvun lopulta viime vuoden loppupuolelle ja erityisesti vuosien 1994-1998 opetuksen huippuyksiköiden valintaa.

K etosen ja Nyyssölän ydinkysymykset ovat: Miten palkittavat opetuksen huippuyksiköt on valittu? Mitkä ovat olleet valintaperustelut? Päähuomio on siis huippuyksiköiden valinnassa. Samalla he kuitenkin jäljittävät myös tuloksellisuusajattelun alkuvaiheita ja sitä, miten yliopistojen tulosohjaus johti huippuyksiköiden valintaan ja palkitsemiseen. Tutkimusaineisto koostuu pääasiassa erilaisista opetusministeriön ja korkeakouluneuvoston asiakirjoista, joita täydentää laitosjohtajille suunnattu postikysely.

Raportissa voi nähdä nel-

jä osaa. Ensimmäinen osa käsittelee tuloksellisuusperiaatetta korkeakoulujen ohjauksessa, toinen huippuyksikköajattelun syntyä ja huippuyksiköiden valintaa ja kolmas laitosjohtajien näkemyksiä palkitsemisen politiikasta. Lopuksi tekijät hahmottelevat huippuyksikköpolitiikan tulevaisuuden haasteita.

Johdantona tarkastellaan korkeakoulujen ohjausjärjestelmiä tuloksellisuusajattelun ja erilaisten rahoitusmallien näkökulmasta sekä korkeakoulu- ja tiedepolitiikan ohjausjärjestelmään tuomien ristipaineiden kannalta. Hallinnon näkökulmakin vilahtaa mukana, kun koulutustoiminnalle ei löydy omaa rationaalisuuttaan, vaan se "sijoittuu tutkimuksen ja hallinnon rationaalisuuden ideaalityyppien väliin, lähemmäksi tutkimusta kuin hallintoa".

$\mathrm{H}$ uomattavasti laajemmin paneudutaan tuloksellisuusperiaatteen leviämiseen ensin korkeakoulu- ja tiedepoliittisiin kannanottoihin ja vähitellen myös korkeakoulujen arkeen. Ratkaisevaksi ajankohdaksi osoittautuu 1980-luvun puoliväli. Vuonna 1986 säädetty korkeakoululaitoksen kehittämislaki sisälsi vaatimuksen korkeakoulujen tuloksellisuuden parantamisesta, ja lakiin liittyvä valtioneuvoston periaatepäätös edellytti - kehittämislain mukaisen voimavarojen lisäämisen ehtona -, että korkeakoulujen tavoitteellisen johtamisen edellytyksiä parannetaan ja korkeakoulujen mahdollisuutta itse päättää niille osoitettujen mää- rärahojen käytöstä lisätään. Muiden ehtojen joukossa oli $\mathrm{mm}$. toiminnan arviointijärjestelmän käyttöönotto. Oli syntynyt korkeakoulujen ohjauksen huoneentaulu.

\section{KOTA ja tuloksellisuusajattelu}

T oinen merkkipaalu 1980-luvun puolivälissä oli korkeakoulujen toiminnan arviointimenetelmien kehittämistyöryhmän, ns. KOTA-työryhmän työ, joka ajallisesti edelsi edellä mainittua valtioneuvoston periaatepäätöstä ja joka näyttää tuoneen tuloksellisuuden käsitteen laajempaan keskusteluun. Työryhmän työn seurauksena syntyi nykyinen KOTA-tietokanta. Työryhmän puheenjohtajana oli arviointineuvoston nykyinen puheenjohtaja, Tampereen yliopiston aikaisempi rehtori Jarmo Visakorpi. Tuloksellisuusajattelu alkoi vähitellen siirtyä suunnitteluasiakirjoista arkiseen työhön.

Arviointi ilmaantui tekijöiden mukaan tiedepoliittisiin asiakirjoihin jo 1970-luvun lopulla, ja 1980-luvun alkupuolen arviointikysymykset, jotka olivat esillä perustutkimuksen työryhmän mietinnössä, perustutkimustyöryhmä II:n muistiossa ja valtion tiedeneuvoston katsauksessa, vaikuttavat vieläkin hyvin ajankohtaisilta: esimerkiksi käytetäänkö arviointia rahanjaon vai kehittämisen välineenä. 
$\mathrm{M}$ iten sitten päädyttiin huippuyksiköihin? Ajatukset hyvien tutkimusyksiköiden tukemisesta ja heikkojen karsimisesta kiteytyivät perustutkimustyöryhmä 89:n mietinnössä kotimaisten huippuyksiköiden aikaansaamiseksi ja toteuttamiseksi. Kysymys oli siis ennen kaikkea perustutkimuksen rahoituksesta, mutta taustalla näyttää olleen myös tarve torjua uhkaavaa aivovuotoa.

Huippuyksikön käsite oli siis tuttu, kun opetusministeriö tammikuussa 1993 antoi korkeakouluneuvoston tehtäväksi valita enintään 10 yksikköä, "joiden tulokset tutkimustoiminnassa ovat kiistatta korkeaa kansainvälistä tasoa ja jotka ovat menestyksellisesti harjoittaneet tieteellistä jatkokoulutusta”. Kyseeseen tulivat "myös yksiköt, jotka opetustyössä ja opetusmenetelmien kehittämisessä ovat olleet poikkeuksellisen menestyksekkäitä”. Huippuyksiköt ja tuloksellisuusrahan jakaminen kohtasivat, mutta kyseessä eivät olleetkaan vain tutkimuksen huiput, vaan myös opetustyössä ja opetusmenetelmien kehittämisessä menestyksekkäät yksiköt. Samalla aikaisemmassa huippuyksikkökeskustelussa tavoitteeksi asetettu perustutkimuksen rahoituksen pitkäjänteinen turvaaminen näyttää jääneen sivuun.

$\mathrm{M}$ yöhemmin tieteellisen tutkimuksen huippuyksiköiden nimeäminen annettiin Suomen Akatemian tehtäväksi ja korkeakouluneuvosto valitsi koulutuksen ja opetuksen huippuyksiköt vuosille 1995-1998. Ketosen ja Nyyssölän mukaan tehtävä on nyt annettu vuoden 1996 alussa perustetulle arvioin- tineuvostolle. Tässä tekijät ovat kuitenkin ehtineet tapahtumien edelle, sillä tulosjohtamisen kehittämistyöryhmä oli vasta ehdottanut, että arviointineuvosto vastaisuudessa hoitaisi tehtävän.

\section{Huippujen valinnan perusteista}

$\mathrm{M}$ iten huippuyksiköt sitten on valittu? Lyhyesti sanottuna eri tavoin eri vuosina. Yhteistä eri vuosille on kuitenkin se, että valinta on perustunut valittavien yksiköiden omiin hakemuksiin ja korkeakouluneuvoston jäsenten asiantuntemukseen. Ketonen ja Nyyssölä kyselevätkin, onko palkittu todellisista koulutuksellisista ja opetuksellisista ansioista vai eleganteista esityksistä. He selvittävät myös sitä, kenellä oli valtaa korkeakouluneuvoston sisällä eli kenen esitykset menivät läpi. Tähän liittyy tärkeämpi kysymys arvioitsijoiden koulutusalakohtaisesta asiantuntemuksesta ja sen tarpeellisuudesta. Erityisesti kiinnittää huomiota toteamus, että ylioppilaskuntien äänellä ei valinnoissa ole ollut mainittavaa merkitystä.

Entä valintaperustelut? Nekin ovat vaihdelleet, mikä Ketosen ja Nyyssölän mielestä heikentää palkitsemisen ohjausvaikutusta. Kriteereitä ei ole annettu etukäteen tai on annettu luettelo asioista, jotka tulisi ottaa huomioon, mutta joita ei kuitenkaan selvästi ole onnistuttu kytkemään valintaan. Ensimmäistä kertaa lukuunottamatta tutkimusansioilla, joita kyselyyn vastanneet laitosjohtajat pitävät tärkeinä myös opetuksen huippuyksikön kriteerinä, ei näytä ol- leen merkitystä valinnassa.

Tekijöiden mukaan valintaperusteet ovat vaihdelleet korkeakoulupoliittisten suhdanteiden mukaan, kun ensimmäisessä valinnassa korostettiin koulutuksen kykyä reagoida elinkeinoelämän tarpeisiin ja myöhemmissä enemmänkin opetuksen laatua ja sen arvostuksen nostamista. Mielenkiintoinen kysymys saattaisikin olla, ovatko koulutuksessaan ulkoisiin odotuksiin reagoivat ja opetuksen laatua painottavat yksiköt samoja vai eri laitoksia. - Oppimisesta ei tekijöiden mainitsemissa kriteereissä ja valintaperusteissa ole mainintaa.

Laitosjohtajille osoitetun kyselyn anti on kokonaisuuden kannalta harmillisen vähäinen (ja vastausprosentti alhainen). Hyvänä puolena laitosjohtajat pitävät sitä, että huippuyksikköjen nimeäminen lisää opetuksen arvostusta ja motivoi ja kannustaa. Ehkäpä ohjausvaikutusta sittenkin on? Kritiikki kohdistuu valintamenettelyyn ja ei-toivottuihin vaikutuksiin, koulutusalojen vastakkainasetteluun ja ennestäänkin vahvojen ja hyvin resurssoitujen laitosten palkitsemiseen. Kaikista vastanneista 52 prosenttia kokee palkitsemisen vaikuttaneen myönteisesti ja myönteisimmin siihen suhtautuvat palkitut.

$\mathrm{O}$ petusministeriön ja korkeakouluneuvoston asiakirjojen pohjalta tehty työ piirtää suomalaisesta palkitsemisen politiikasta yksityiskohtaisen, mutta asiakirjanmakuisen kuvan, jota laitosjohtajille osoitettu kysely rikastaa vähemmän kuin olisi toivonut. Päättäjien ja valmisteluun osallistuneiden haastattelut olisivat antaneet li- 
säväriä - mutta vaatineet tietenkin melkoisen työpanoksen.

Raportin johdannossa tekijät kyselevät ydinkysy-mystensä lisäksi myös sitä, miten ulkomaiset esikuvat vai-kuttivat tuloksellisuusajattelun läpimurtoon, mutta tältä osin vastaus jää varsin niukaksi. Muutamassa kohdassa viitataan OECD:n kautta saatuihin vai-kutteisiin ja ruotsalaisiin esi-merk-keihin, mutta muuten kytkentä kansainvälisiin virtauksiin puuttuu. Syntyy kummallinen kuva miltei umpiossa kehittyneestä suomalaisesta korkeakoulupolitiikasta. Lukuisat, kaiketi kiireestä johtuvat kielivirheet ärsyttävät.
$\mathrm{P}$ uutteineenkin raportti on mielenkiintoinen peruspaketti ajankohtaisen asian taustasta.

Lopussa, hahmotellessaan huippuyksikköpolitiikan tulevaisuuden haasteita Ketonen ja Nyyssölä nostavat esiin kiintoisia kysymyksiä. Huippuyksikköpolitiikalle he näkevät kaksi mahdollista linjaa: "alkuperäisen" tiedepoliittisen pyrkimyksen osoittaa voimavaroja pitkäjänteiseen tutkimustyöhön, ja nykyisen, lyhytaikaista voimavarojen lisäystä tarkoittavan palkitsemisen politiikan. Edellinen on heidän mukaansa ainoaa oikeaa huippuyksikköpolitiikkaa, jälkimmäinen ilmeisesti todennäköistä, sillä pohdiskelu liittyy juuri palkitsemisen politiikan ongelmiin.

Pitäisikö esimerkiksi jotenkin seurata sitä, miten palkintoa on käytetty? Tai mitä hyötyä opetuksen huippuyksiköillä on statuksestaan? Näiden lisäksi voisi kysyä, onko opetuksen huippuyksikköjen nimeäminen vaikuttanut opetuksen kehittämiseen yliopistoissa - siihenhän ilmeisesti pyritään, kun taas kirjoittajat epäilevät, että kehitystä on tapahtunut vain hakemuksissa - ja millä tavoin?

Anna-Maija Liuhanen 